\section{Modeling of early stage litter decomposition in Mediterranean mixed forests: functional aspects affected by local climate}

\author{
Marcello Vitale ${ }^{(1)}$, Flavia Savi ${ }^{(1)}$, Daniela Baldantoni ${ }^{(2)}$, Fabio Attorre ${ }^{(1)}$
}

Litter decomposition is an important process affecting the carbon balance of forest ecosystems. In the Mediterranean area, seasonal changes, local climate variations and structural characteristics of forest stands may have a remarkable effect on decomposition rates. In this study, we developed a semi-empirical model for assessing the early-stage litter degradation dynamics over two years (2011-2012) in three sites located along a north-south transect in central Italy (Umbria, Lazio and Campania) and covered by sub-Mediterranean mixed woods. Adequate time-depending functions modeling the seasonal fluctuations of decomposition rates were developed and combined with suitable algorithms taking into account the effect of local climatic conditions. Leaf litter was split into the labile (easy-degraded) and recalcitrant subcomponents. The effects of temperature and moisture were modeled by specific equations and decomposition rates by time-depending functions. Equations were calibrated on field experimental data obtained by the litterbag method at the three study sites. Model validation revealed an excellent correlation between observed and predicted values ( $R^{2}$ between 0.89 and 0.95$)$, indicating the accuracy of the model in predicting differences in decomposition rates among different local climatic conditions. The simple structure and the reliability of predictions are important characteristics of the model developed, that may be considered an operative alternative to other currently used methods aimed at assessing $\mathrm{CO}_{2}$ release and carbon balance of forest ecosystems.

Keywords: Decomposition Rate, Litterbags, Mediterranean Climate, Semi-empirical Models

\section{Introduction}

Litter decomposition is a central feature of the ecosystem dynamics, being involved in the carbon and nutrient cycling through the active transformation of organic to inorganic matter (Burke et al. 2003). Decomposition entails a combination of physic-chemical and biological processes. Substrate quality and climate are among the most important factors affecting litter decay (Meentemeyer 1978, Hobbie 2005). For instance, the overall chemical and structural characteristics of the leaf litter affect the length of decomposition phases, which are characterized by different degradation rates (Berg \& McClaugherty

2008). The role of climatic parameters in the decomposition process is still a matter of debate, though temperature and moisture seem to influence decomposition by altering the activity of decomposers (Berg \& McClaugherty 2008). The response of decomposition rates to such parameters is a key issue that scientists have been investigating by modeling. Jenny et al. (1949) first proposed a negative exponential function to quantify the time-based reduction of dead mass in the soil. This first model was further developed by Olson (1963). In this frame, numerous models have been developed in order to predict carbon storage and fluxes in many ter-

$\square$ (1) Department of Environmental Biology, "Sapienza" University of Rome, p.le Aldo Moro 5, I-00185 Rome (Italy); (2) Department of Chemistry and Biology, University of Salerno, v. Giovanni Paolo II 132, I-84084 Fisciano (SA, Italy)

@ Marcello Vitale (marcello.vitale@uniroma1.it)

Received: Dec 13, 2013 - Accepted: Aug 27, 2014

Citation: Vitale M, Savi F, Baldantoni D, Attorre F, 2014. Modeling of early stage litter decomposition in Mediterranean mixed forests: functional aspects affected by local climate. iForest 8: 517-525 [online 2014-11-18] URL: http://www.sisef.it/iforest/contents/? id=ifor $1202-007$

Communicated by: Giorgio Matteucci restrial ecosystems. Such models are mainly based on two assumptions: (i) the decomposition process gradually alters the chemical composition of dead mass (i.e., fresh litter to humus); (ii) organic matter is made of a mixture of chemical compounds decaying at different rates. Models like CENTURY (Parton et al. 1994) and ROMUL (Chertov et al. 2001) are based on the first assumption, whereas others such as MBL GEN (Rastetter et al. 1991), DOCMOD (Currie \& Aber 1997), and FLDM (Zhang et al. 2007) are based on the second. Generally, these models consider the decomposition rate as a constant value, corrected by specific algorithms to take into account the climate variability. Under this assumption, however, the litter quality does not appreciably change with time. Instead, biochemical changes are known to affect the decomposition rates of organic matter along the process: more labile components are degraded first, while recalcitrants have a tendency to accumulate (Minderman 1968). Rovira \& Rovira (2010) overcame this contradiction by developing equations describing the substrate-based fluctuations of decomposition rates occurring over time. Previous reports assumed that the decomposition rates decrease over time (Carpenter 1982, Ezcurra \& Becerra 1987, Yang \& Janssen 2000). This is not always true in natural environments, where litter decay can fluctuate either for seasonal cycles or different patterns of microbial colonization (Rovira \& Rovira 2010). However, the equations proposed by Rovira \& Rovira (2010) are too general to grasp the difference among local climates.

The decomposition dynamics have frequently been modeled for temperate ecosystems (Parton et al. 1994, Liski et al. 2005). On the other hand, studies concerning this fundamental process in the Mediterranean basin are scarce, despite the importance of this region within the global change context. Indeed, Mediterranean area is considered one of the main hot spots in future climate change projections (Giorgi 2006). Moreover, the climate of the Mediterranean area is srongly affected by local features, such as topography, presence of water bodies and different vegetation cover, resulting in a great spatial variability (Giorgi \& Lionello 2008). To successfully simulate the decomposition dynamics in these environments, adequate time-depending functions describing the fluctuations of the decomposition rates have to be developed and combined with suitable algorithms for local climate effects.

In this study, we developed a semi-empirical model for assessing the early-stage litter degradation dynamics over two years (20112012) in three sites located along a north-tosouth transect in central Italy (Umbria, Lazio and Campania) and covered by sub-Mediter- 
ranean mixed woods. Two litter compartments showing different litter qualities and decomposing at different rates were considered. The role of different local climates has been taken into consideration by applying multiplicative functions that influenced the simulated decomposition process. The decomposition model has been parametrized using field data collected in the Lazio test site, and then applied to the other test sites (Umbria and Campania) for cross-validation The use of leaf litter collected from a single site (Monti Lucretili) also in the other sites avoided possible influences resulting from using different leaf material and allowed to better test the temperature-based heterotrophic respiration for the carbon balance

\section{Material and Methods}

\section{Study areas and climatic data}

The study has been carried out in three sites from central Italy located along a northsouth transect (Tab. 1): (i) the Boschi di Pietralunga (Umbria), a site of community importance; (ii) the Regional Park of Monti Lucretili (Lazio); and (iii) the Regional Park of Monti Picentini (Campania). These areas were characterized by mixed woods where the most represented species were Quercus cerris (Turkey oak), Acer obtusatum (Italian maple), Carpinus betulus (European hornbeam), Acer campestre (field maple), Cornus mas (European cornel), Fraxinus ornus (manna ash) and Sorbus aria (common whitebeam). Canopies at the study sites were as much dense as the sunlight barely penetrated during the vegetative season. The physical texture of soil was silt-loam for the three test sites, and the substrate was calcareous. Some climatic data of the test sites are reported in Tab. 1 for the years 2008-2011. The climate was typical Mediterranean: pre- cipitation occurred mainly in autumn and winter, whereas summers were hot and dry. Climatic data were provided by: the automatic monitoring station located at Colle Badia Petroia, Città di Castello (Perugia) for the Boschi di Pietralunga; the Integrated Agricultural and meteorological Service of the Lazio Region (ARSIAL, monitoring station of Licenza - Rome) for the Regional Park of Monti Lucretili; the National Service of Civil Protection, section of Montecorvino Rovella (Salerno) for the regional Park of Monti Picentini.

The leaf litter decomposition experiment conducted in Monte la Sauceda, southwest Spain $\left(36^{\circ} 30^{\prime} \mathrm{N}, 5^{\circ} 35^{\prime} \mathrm{W}, 432 \mathrm{~m}\right.$ a.s.l. Gallardo \& Merino 1993) was used for a further validation of the model. The vegetation at this test site was dominated by cork oak (Quercus suber) forests, mixed with winter deciduous oaks (Quercus canariensis). The soil was sandy, with small inclusions of loam and clay. This area showed the typical winter-wet and summer-dry pattern of the Mediterranean climate. Mean annual temperature was $16.2{ }^{\circ} \mathrm{C}$ and the average annual precipitation about $1600 \mathrm{~mm}$. Further information on the experimental site in Monte la Sauceda are reported by Gallardo \& Merino (1993).

\section{Field data collection}

The litterbag approach (Wieder \& Lang 1982 ) is widely used to study the decomposition process at the soil surface. Two kinds of $20 \times 15 \mathrm{~cm}$ nylon bags with different meshes ( 3 and $10 \mathrm{~mm}$ ) have been arranged. The first bag type ( $3 \mathrm{~mm}$ - fine mesh, FM) was chosen to exclude the meso-fauna, and to minimize particle inputs and biomass loss as well. The second type $(10 \mathrm{~mm}$ - coarse mesh, CM) was used to allow the soil microand meso-fauna to reach the litter contained in the bags.

During October 2010, leaves from branches of Italian maple, field maple and European hornbeam have been collected from trees growing in the Regional Park of Monti Lucretili. Such unique sampling site has been chosen in order to exclude differences in the physical and chemical properties of leaves due to differences at growing sites. In this way, the decomposition rates were only dependent on local climate, local micro- and meso-fauna and soil properties of the test sites. Sampled leaves were pooled and airdried at room temperature until reaching a constant weight. Three grams of leaf biomass were enclosed in each bag, according to the percentage of presence of species in the forest stand: $40 \%$ Italian maple, $40 \%$ field maple and $20 \%$ European hornbeam. Sixty fine mesh litterbags and sixty coarse mesh litterbags have been placed at the soil surface in each site in January 2011, and periodically collected (six items for each bag type) until June 2012. Moreover, six items of each bag-type have been used to determine the weight losses due to manipulation, i.e., items have been chemically processed after oven-drying at $50{ }^{\circ} \mathrm{C}$ for 72 hours, in order to determine their initial content of lignin, nitrogen $(\mathrm{N})$ and carbon $(\mathrm{C})$. One $\mathrm{mm}$ mesh size litterbags have been used to enclose separately two grams of Quercus suber and $Q$. canariensis leaves in the experiment at Monte la Sauceda test site. Details on litter quality, field and analytical methods performed in the experiment of Monte la Sauceda were reported by Gallardo \& Merino (1993).

\section{Mass loss and determination of lignin, nitrogen and carbon content}

Leaves from litter bags were carefully cleaned with ultra-pure distilled water to

Tab. 1 - Main characteristics of the three test sites analyzed for model calibration. (FC): field capacity $\left(\mathrm{mm} / \mathrm{m}^{2}\right)$ of the upper 30 -cm soil layer (measured value); (WP): wilting point $\left(\mathrm{mm} / \mathrm{m}^{2}\right)$ of the upper $30-\mathrm{cm}$ soil layer (measured value); $\left(\mathrm{T}_{\text {mean }}\right)$ : mean annual temperature $\left({ }^{\circ} \mathrm{C}\right) ;\left(\mathrm{T}_{\text {jan }}\right)$ : average of January minimum temperature $\left({ }^{\circ} \mathrm{C}\right)$; (SDS): Mitrakos' index of summer drought stress; (WCS): Mitrakos' index of winter cold stress (Mitrakos 1980).

\begin{tabular}{|c|c|c|c|c|c|c|c|c|c|c|c|}
\hline Site & Coordinates & $\begin{array}{c}\text { Elevation } \\
\text { (m a.s.l.) }\end{array}$ & Aspect & $\begin{array}{c}\mathrm{FC} \\
\left(\mathrm{mm} / \mathrm{m}^{2}\right)\end{array}$ & $\begin{array}{c}\mathbf{W P} \\
\left(\mathrm{mm} / \mathbf{m}^{2}\right)\end{array}$ & Year & $\begin{array}{l}\mathbf{T}_{\text {mean }} \\
\left({ }^{\circ} \mathbf{C}\right)\end{array}$ & $\begin{array}{l}\mathbf{T}_{\mathrm{Jan}} \\
\left({ }^{\circ} \mathbf{C}\right)\end{array}$ & $\begin{array}{c}\text { Rainfall } \\
\text { (mm) }\end{array}$ & SDS & WCS \\
\hline Boschi di & $12^{\circ} 25^{\prime} 27.48^{\prime \prime} \mathrm{E}$ & 643 & $\mathrm{~N}$ & 95.4 & 27 & 2008 & 14.2 & 3 & 969.2 & 56.3 & 64.3 \\
\hline \multirow[t]{4}{*}{ Pietralunga } & $43^{\circ} 25^{\prime} 47.64^{\prime \prime} \mathrm{N}$ & & & & & 2009 & 13.5 & 1 & 897.6 & 42.3 & 71.6 \\
\hline & & & & & & 2010 & 12.8 & -0.1 & 1254.4 & 33.7 & 72 \\
\hline & & & & & & 2011 & 13.9 & 1.4 & 638.4 & 32.9 & 66.1 \\
\hline & & & & & & average & 13.6 & 1.3 & 939.9 & 41.3 & 68.5 \\
\hline Monti & $12^{\circ} 51^{\prime} 51.12^{\prime \prime} \mathrm{E}$ & 843 & $\mathrm{~N}$ & 94.2 & 29.1 & 2008 & 14.5 & 2.8 & 1449.8 & 42.1 & 61.9 \\
\hline \multirow[t]{4}{*}{ Lucretili } & $42^{\circ} 02^{\prime} 56.40^{\prime \prime} \mathrm{N}$ & & & & & 2009 & 13.8 & 2.2 & 1598.2 & 9.5 & 61.6 \\
\hline & & & & & & 2010 & 13.1 & 0.7 & 1569.4 & 3.2 & 69.1 \\
\hline & & & & & & 2011 & 14.4 & 2.1 & 908.8 & 22.9 & 58.9 \\
\hline & & & & & & average & 14 & 2 & 1381.6 & 19.4 & 62.9 \\
\hline Monti & $15^{\circ} 00^{\prime} 36.72^{\prime \prime} \mathrm{E}$ & 612 & $\mathrm{~N}$ & 100.5 & 36.1 & 2008 & 16.3 & 6.2 & 1322.6 & 58.9 & 33.1 \\
\hline \multirow[t]{4}{*}{ Picentini } & $40^{\circ} 42^{\prime} 03.60^{\prime \prime} \mathrm{N}$ & & & & & 2009 & 16.4 & 6.8 & 1119 & 48.2 & 32.5 \\
\hline & & & & & & 2010 & 15.4 & 4.8 & 1819.2 & 33.3 & 40.3 \\
\hline & & & & & & 2011 & 15.9 & 5.3 & 1014.4 & 55.1 & 35.7 \\
\hline & & & & & & average & 16 & 5.78 & 1318.8 & 48.9 & 35.4 \\
\hline
\end{tabular}


eliminate soil particles and meso-fauna at each sampling. After cleaning, leaves were oven-dried at $50{ }^{\circ} \mathrm{C}$ for 72 hours and then weighted. The litter mass loss was calculated as percentage of variation from the initial weight. Since small amounts of soil mineral elements could contaminate leaf samples in the bags, the remaining mass of each sample was calculated by detracting its ash content from the dry mass. The ash content was determined by burning $0.3 \mathrm{~g}$ of each sample at $550{ }^{\circ} \mathrm{C}$ for 2 hours in a high temperature electric oven (GenLab, UK). Leaves were pulverized in a planetary ball mill (PM400, Retsch - Germany). Lignin content of the mixed species litter was determined using the method by Van Soest \& Wine (1968), modified as described by Fioretto et al (2005). N and C were measured by a CHNSO Analyzer (Thermo FlashEA1112, Thermo Fisher Scientific Inc. - USA).

\section{Model description}

\section{Theory and basic assumptions}

Time-dependent simulation of leaf litter decay has been performed on a dynamic semi-empirical model based on the Olson's model (1963). It was assumed that the decaying litter lost a proportion of its mass per unit of time (Olson 1963). In this study, litter was considered to be composed of two main components constituted by lignin in the first component (recalcitrant litter) and by cellulose, hemicelluloses and soluble compounds in the second component (labile litter). Fur-

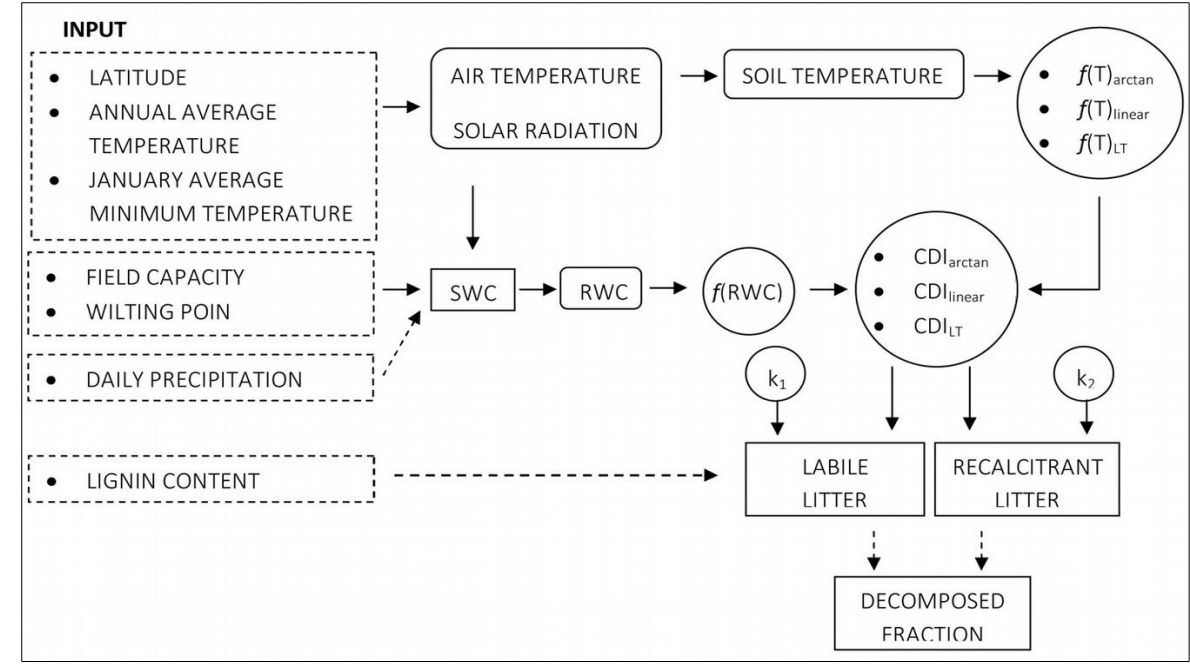

Fig. 1 - Conceptual diagram of the decomposition model. Dashed boxes refer to input variables, squares are stocks, rounded square are driver variables, circles represent specific information dealing with model control, dashed arrows denote fluxes and solid arrows represent impacts.

thermore, these components were characterized by different decomposition rates (Louisier \& Parkinson 1979), though neither group of compounds decays independently, as lignin physically can protect great part of the cellulose and hemicelluloses from decomposition (Cooke \& Whipps 1993). Decomposition rates of these groups change over time, in relation to the progressive variation in the proportions of different compounds. Finally, it was also assumed that mi- crobial activity depended on optimal temperature and moisture conditions (Olson 1963, Meentemeyer 1978, Berg et al. 1993, Liski et al. 2003), though the relationship between temperature and decomposition rate is still debated (Giardina \& Ryan 2000, Epstein et al. 2002).

\section{Model structure and equations}

The semi-empirical model of litter decomposition (Fig. 1) has been developed using

Tab. 2 - Parameter and equations used for litter decomposition modeling. $\left(T_{\text {soil }}\right)$ : soil temperature at depth $10 \mathrm{~cm}$; $\left(T_{\text {air }}\right)$ : air temperature; $f(T)_{\text {arctan, }} f(T)_{\mathrm{LT}}, f(T)_{\text {linear: }}$ temperature effect on decomposition rates; (meltsnow): water from the snow pack; $(S W C)$ : soil water content; $(R W C)$ : relative water content; $(W P)$ wilting point; $(F C)$ : field capacity; (intloss): interception per rain events; $(K C)$ : crop coefficient; $\left(E t_{\mathrm{rA}}\right)$ : annual real evapotranspiration; $\left(E T_{0 \mathrm{~A}}\right)$ : annual potential evapotranspiration; $\left(E T_{0}\right)$ : potential evapotranspiration; $(S)$ : maximum quantity of water absorbed after run-off start; $(L A I)$ : leaf area index; $(C N)$ : run-off curve number; $f(R W C)$ : moisture effect on decomposition rates; $(w)$ : lignin percentage of leaf litter; $\left(k_{1}\right)$ : decomposition rate of labile compounds; $\left(k_{2}\right)$ : decomposition rate of recalcitrant compounds.

\begin{tabular}{|c|c|c|c|}
\hline Parameter & Units & Equations and values & Source \\
\hline $\begin{array}{l}T_{\text {soil }} \\
\quad\end{array}$ & ${ }^{\circ} \mathrm{C}$ & $0.769+0.826 \cdot T_{\text {air }}$ & This work \\
\hline$f(T)_{\text {arctan }}$ & dimensionless & $0.56+\left(1.46 \cdot \arctan \left(\pi \cdot 0.0309 \cdot\left(T_{\text {soil }}-15.7\right)\right)\right) / \pi$ & Del Grosso et al. 2005 \\
\hline$f(T)_{\mathrm{LT}}$ & dimensionless & $0.57658 \cdot \exp ^{\left(308.56 \cdot\left((1 / 56.02)-\left(1 /\left(273-T_{\text {soil }}-227.13\right)\right)\right)\right)}$ & Lloyd \& Taylor 1994 \\
\hline$f(T)_{\text {linear }}$ & dimensionless & $0.198306+T_{\text {soil }} \cdot 0.036377$ & Adair et al. 2008 \\
\hline meltsnow & $m m$ day $^{-1}$ & $0.66 \cdot T_{\text {air }}$ & Parton et al. 1994 \\
\hline$S W C$ & $m m$ day $^{-1}$ & $($ rainfall + meltsnow $)-\left(\right.$ intloss + runoff $\left.+E T_{0}\right)$ & This work \\
\hline$R W C$ & unitless & $(S W C-W P) /(F C-W P)$ & Del Grosso et al. 2005 \\
\hline intloss & $\mathrm{mm} \mathrm{day}^{-1}$ & rain $\cdot\left(1-\exp ^{(-K C \cdot L A I)}\right)$ & Ritchie 1972 \\
\hline$K C$ & dimensionless & $E T_{\mathrm{rA}} / E T_{0 \mathrm{~A}}$ & Allen et al. 1998 \\
\hline$E T_{\mathrm{rA}}$ & mm year $^{-1}$ & $P A /\left(\sqrt{ }\left(0.9+\left(P A^{2} /\left(300+25 \cdot T A^{3) 2}\right)\right)\right)\right.$ & Turc 1954 \\
\hline$E T_{0}$ & $m m$ day $^{-1}$ & $0.408(R n-G)+\gamma \cdot\left(900 /\left(T_{\text {air }}+273\right) \cdot \mathrm{u}_{2} \cdot\left(\mathrm{e}^{\circ}(T)-\mathrm{e}_{\mathrm{a}}\right)\right) /\left(\Delta+\gamma \cdot\left(1+0.34 \cdot u_{2}\right)\right)$ & Allen et al. 1998 \\
\hline runoff & mm day ${ }^{-1}$ & $\left(((\text { rainfall }- \text { intloss })-(0.2 \cdot S))^{2}\right) /(($ rainfall - intloss $)+(0.8 \cdot \mathrm{S}))$ & Steward et al. 1976 \\
\hline$S$ & $\mathrm{~mm}$ & $254 \cdot[(100 / C N)-1]$ & Steward et al. 1976 \\
\hline$L A I$ & dimensionless & $2.56 /\left[1+1430 \cdot \exp ^{(-0.0471 \cdot t)}\right]$ & Calibration \\
\hline$C N$ & dimensionless & 55 & Steward et al. 1976 \\
\hline$f(R W C)$ & dimensionless & $5 \cdot(0.287+(\arctan (\pi \cdot 0.009 \cdot(R W C \cdot 10-17.47))) / \pi)$ & Del Grosso et al. 2005 \\
\hline$w$ & $\%$ & 38 & This work \\
\hline$k_{1}$ & $\%$ day $^{-1}$ & $1 /\left(-2.04 \cdot 10^{3}+1.99 \cdot 10^{3} \cdot t^{0.0482}\right)$ & This work \\
\hline$k_{2}$ & $\%$ day $^{-1}$ & $9.09 \cdot 10^{-4}+2.06 \cdot 10^{-5} \cdot t-4.31 \cdot 10^{-8} \cdot t^{2}$ & This work \\
\hline
\end{tabular}


the software platform STella ${ }^{\circledR}$ v. 7.0.3 (Isee Systems Inc., USA), an object-oriented program (OOP), comprising several interrelated modules. The organization into small autonomous units (modules) allows much more flexibility in modeling complex processes such as litter decomposition, being affected by several environmental and biological components. Furthermore, a single specific function performed in a module can be replaced by a similar one with no need of rearranging the whole model. Also, different models can be linked each other in order to explore more processes mutually interacting at the same time.

Sub models and their equations to simulate the parameters are described below (see also Tab. 2).

\section{Climatic module}

Data concerning latitude, annual average air temperature $\left(T A,{ }^{\circ} \mathrm{C}\right)$ and January minimum average air temperature $\left(T_{\text {Jan, }}{ }^{\circ} \mathrm{C}\right)$ calculated over four years (2008-2011) have been included in the model (climatic static database) as input parameters for simulating solar radiation $\left(\mathrm{W} \mathrm{m}^{-2}\right)$ and daily average air temperature $\left(T_{\text {air }},{ }^{\circ} \mathrm{C}\right)$ using the climate algorithm reported by Vitale et al. (2003). Soil temperature $\left(T_{\text {soil, }}{ }^{\circ} \mathrm{C}\right)$ has been calculated by using an empirical equation (eqn. $1-r^{2}=0.99$ ) derived by fitting air and soil temperature database (2007-2011) supplied by climatic monitoring station of Licenza, located in the Regional Park of Monti Lucretili (Lazio, central Italy - eqn. 1):

$$
T_{\text {soil }}(t)=0.769+0.826 \cdot T_{\text {air }}(t)
$$

where $t$ is the day of the year.

\section{Hydrological module}

This module has been developed to simulate the soil water content $\left(S W C(t), \mathrm{mm} \mathrm{day}^{-1}\right)$ in the first $30-\mathrm{cm}$ depth of soil. Air temperature $\left({ }^{\circ} \mathrm{C}\right)$, precipitation $(\mathrm{mm})$ and water holding capacity $\left(F C(t), \mathrm{mm}^{-1 a y}{ }^{-1}\right)$ have been included as input parameters. When the $S W C$ was below the water holding capacity it was cal-

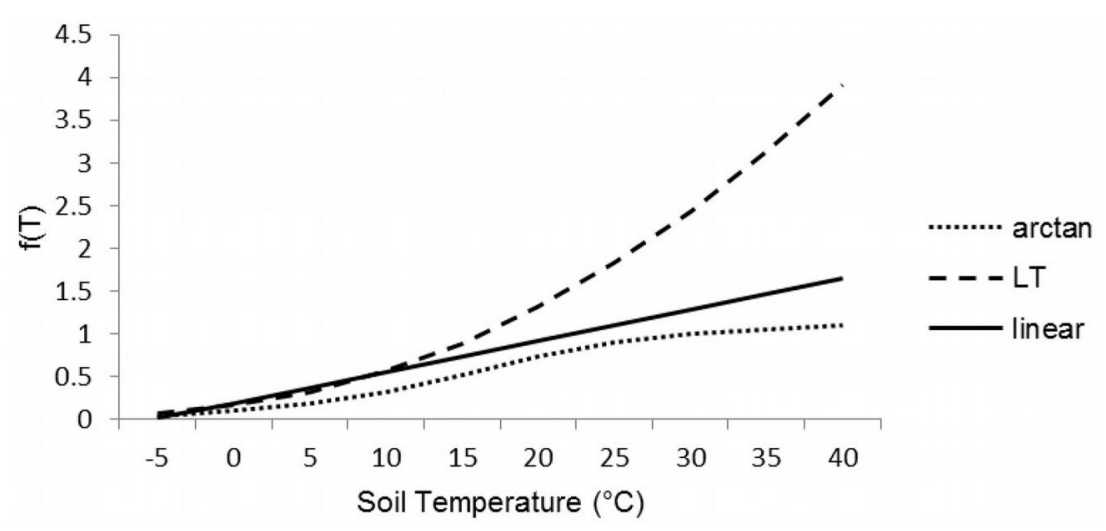

culated from the in-coming and out-coming water balance as follows (eqn. 2):

$$
\begin{aligned}
S W C(t) & =[\operatorname{rain}(t)+\text { meltsnow }(t)]- \\
& -\left[\operatorname{intloss}(t)+\operatorname{runoff}(t)+E T_{0}(t)\right]
\end{aligned}
$$

where meltsnow $\left(\mathrm{mm} \mathrm{day}^{-1}\right)$ was the in-coming water supply from melting snow, calculated by a temperature-dependent linear equation according to Parton et al. (1994); intloss $\left(\mathrm{mm} \mathrm{day}^{-1}\right)$ was the water interception by the canopy (Ritchie 1972), which, in turn, is a function of the leaf area index $\left(L A I, \mathrm{~m}^{2}\right.$ leaf $\mathrm{m}^{-2}$ ground). The $L A I(t)$ (eqn. 3) has been simulated by a logistic equation, parametrized using empirical data derived by Gratani \& Foti (1998) for a mixed deciduous forest located in Abruzzi (central Italy), similar to the woody stands considered in this study (eqn. $3)$ :

$$
L A I(t)=\frac{2.56}{1+1430 \cdot \exp (-0.047 \cdot t)}
$$

The time period considered for the intloss modeling was from the $100^{\text {th }}$ to the $281^{\text {th }}$ day of the year. The runoff (runoff $\left.(t), \mathrm{mm}^{\mathrm{day}}{ }^{-1}\right)$ was simulated according to Steward et al. (1976). In this module, we used the runoff model calibrated for woods protected from grazing, and soil adequately covered by litter and brush (Steward et al. 1976). The potential evapotranspiration $\left(E T_{\mathrm{o}}(t), \mathrm{mm}\right.$ day $\left.^{-1}\right)$ was calculated by a modified Penman-Monteith equation, as reported by Allen et al. (1998). $S W C(t)$ was considered equal to $F C(t)$ and the excess water was assumed to percolate to the bottom layer when the hydrological balance exceeded the $F C(t)$. Water holding capacity $F C(t)$ and wilting point were calculated using the soil calculator algorithm of the CENTURY model (Parton et al. 1994) based on equations developed by Gupta \& Larson (1979) and Rawls et al. (1982). Soil calculator algorithm needed of sand, clay and silt fractions as input.

\section{Decomposition module}

Litter decomposition followed two exponential dynamics made as function of time and

Fig. 2 - Trends of the three soil temperature-based functions $f(T)$ included in the model.

climatic conditions (eqn. 4):

$$
M(t)=M_{1} \cdot e^{\left(-k_{1} \cdot C D I_{i} \cdot t\right)}+M_{2} \cdot e^{\left(-k_{2} \cdot C D I_{j} \cdot t\right)}
$$

where $M(t)$ was the amount of litter at time $t$, $M_{1}$ and $M_{2}$ were the initial amounts of the labile and recalcitrant components (determined by the fraction of initial litter lignin content) and $k_{1}$ and $k_{2}$ their decomposition rates, respectively. $C D I_{\mathrm{i}, \mathrm{j}}$ were the climatic decomposition indexes (Adair et al. 2008), specific for each pool and accounting for local climate conditions. Decomposition rates related to labile and recalcitrant components $\left[k_{1}(t)\right.$ and $k_{2}(t)$ ] were not constant but varying over time. The equations describing the decomposition rates for the two compartments $M_{1}$ and $\mathrm{M}_{2}$ were obtained by interpolation of decomposition rates of non-lignin and lignin fractions, respectively, and estimated by biomass losses data obtained in the Lucretili Regional Park (Lazio, central Italy) test site during the entire experimental time period (eqn. 5):

$$
k(t)=\frac{\ln \left(M_{0}\right)-\ln \left(M_{t}\right)}{t}
$$

where $k(t)$ is the decomposition rate $\left(\mathrm{day}^{-1}\right)$, $M_{0}$ was the initial mass (\%) and $M_{\mathrm{t}}$ was the mass (\%) at time $t$ (days).

Then, the time-based equations of $k_{1}$ and $k_{2}$ have been chosen by a best fitting procedure performed by CURVE EXPERT BASIC 1.4 shareware software (Hyams 2010 - eqn. 6, eqn. 7):

$$
\begin{aligned}
& k_{1}(t)=\frac{1}{-2.04 \cdot 10^{3}+1.99 \cdot 103 \cdot t^{\left(4.82 \cdot 10^{-2}\right)}} \\
& k_{2}(t)=9.09 \cdot 10^{-4}+2.06 \cdot 10^{-5}-4.31 \cdot 10^{-8} \cdot t^{2}
\end{aligned}
$$

where $t$ is the day of the year.

The decomposition rates have been corrected by incorporating the climatic decomposition index $(C D I)$ to account for climatic variability. $C D I$ simulated the soil moisture $[f(R W C)]$ and temperature $\left[f(T)_{\mathrm{i}}\right]$ effects as follows (eqn. 8 - Adair et al. 2008):

$$
C D I=f(R W C) \cdot f(T)_{i}
$$

The effect of temperature has been simulated taking into account three functions from the literature, suited for Mediterranean conditions (Fig. 2). Indeed, the majority of litter decomposition models were realized for temperate climates and their equations implied a marked sensitivity to temperature already above $10{ }^{\circ} \mathrm{C}$ (Adair et al. 2008). The equations were $f(T)_{\text {arctan }}$ (Del Grosso et al. 2005), $f(T)_{\mathrm{LT}}$ (Lloyd \& Taylor 1994) and $f(T)_{\text {linear }}$ (Adair et al. 2008). In details (eqn. 9, eqn. 10 , eqn. 11):

$$
\begin{aligned}
& f(T)_{\arctan }=0.56 / \pi+ \\
& +\left[1.46 \cdot \arctan \left(\pi \cdot 0.0309 \cdot\left[T_{\text {soil }}-15.7\right]\right)\right] / \pi
\end{aligned}
$$




$$
\begin{aligned}
& f(T)_{L T}=0.576 \cdot e^{308.56 \cdot\left[(56.02)^{-1}-\left(273+T_{\text {soil }}-227.13\right)^{-1}\right]} \\
& f(T)_{\text {linear }}=0.198+T_{\text {soil }} \cdot 0.036
\end{aligned}
$$

The decomposition rates were strongly affected by temperature functions by slowing down of decomposition process of about 85$75 \%$ at low winter temperature. The three functions were affecting decomposition rates in different ways during summer period. The arctan function (eqn. 9) was normalized to 1 at $30{ }^{\circ} \mathrm{C}$, whereas the linear function (eqn. 11) was not normalized, although its slope (0.036) did not allow reaching values $>1.07$ for the range of latitudes considered in this study. The Lloyd \& Taylor's function (eqn 10) had an exponential trend that reached 1 at the soil temperature of $16^{\circ} \mathrm{C}$, after that the function increased rapidly its values doubling the decomposition rates at $27{ }^{\circ} \mathrm{C}$ and triplicating them at $34{ }^{\circ} \mathrm{C}$. The soil moisture effect $[f(R W C)]$ has been simulated according to Del Grosso et al. (2005) as follows (eqn. 12):

$$
f(R W C)=5 \cdot \frac{0.287+\arctan (\pi \cdot 0.09 \cdot R W C-17.47)}{\pi}
$$

The relative water content $[R W C(t)]$ allowed to quantify the water content in the soil by water balance with respect to the previous day. It was calculated by $S W C$ according to Del Grosso et al. (2005). $f(R W C)$ took values ranging from 0.7 to 1.1 when soil $R W C$ was 0 and 1 , respectively. Different $C D I$ s were applied to $M_{1}$ and $M_{2}$ components according to the following conditions (eqn. 13):

$$
M_{t}=\left\{\begin{array}{cl}
M_{1} \cdot \exp \left(-k_{1} C D I_{\text {linear }} t\right)+ & \\
M_{2} \cdot \exp \left(-k_{2} C D I_{\text {linear }} t\right) & \text { if } T_{\text {Jan }}>2.5 \\
M_{1} \cdot \exp \left(-k_{1} C D I_{L T} t\right)+ & \\
M_{2} \cdot \exp \left(-k_{2} C D I_{\text {arctan }} t\right) & \text { if } T_{\text {Jan }} \geqslant 1.5 \\
& \text { and } T_{\text {Jan }} \leqslant 2.5 \\
& \text { and } T I D>12 \\
M_{1} \cdot \exp \left(-k_{1} C D I_{\text {linear }} t\right)+ & \text { if } T_{\text {Jan }} \leqslant 2.5 \\
M_{2} \cdot \exp \left(-k_{2} C D I_{\text {arctan }} t\right) & \text { and } T I D>12
\end{array}\right.
$$

where $T_{\mathrm{Jan}}$ is the minimum average air temperature $\left({ }^{\circ} \mathrm{C}\right)$ in January and $T I D$ is the maximum deviation of $T_{\text {Jan }}$ from annual average temperature $\left({ }^{\circ} \mathrm{C}\right)$.

Further information about decomposition model are reported in Appendix 1.

\section{Statistics}

Multivariate analysis of variance (MANOVA) and principal component analysis (PCA) were performed to test for differences among test sites in the climatic parameters (precipitation, average, minimum and maximum temperature), and to classify all the variables considered in order of importance.

Tab. 3 - Analysis of homogeneity of temperature and precipitation among the studied stands after Tukey's HSD test $(\alpha=0.05)$. $\left(\mathrm{T}_{\text {mean }}\right)$ : average temperature $\left({ }^{\circ} \mathrm{C}\right)$; $\left(\mathrm{T}_{\min }\right)$ : minimum temperature $\left({ }^{\circ} \mathrm{C}\right) ;\left(\mathrm{T}_{\max }\right)$ : maximum temperature $\left({ }^{\circ} \mathrm{C}\right) ;(* * * *)$ : significant homogeneity between site pairs for the parameter considered.

\begin{tabular}{lccc}
\hline Parameter & $\begin{array}{c}\text { Boschi di } \\
\text { Pietralunga }\end{array}$ & Monti Lucretili & Monti Picentini \\
\hline $\mathrm{T}_{\text {mean }}\left({ }^{\circ} \mathrm{C}\right)$ & $* * * *$ & $* * * *$ & - \\
$\mathrm{T}_{\min }\left({ }^{\circ} \mathrm{C}\right)$ & $* * * *$ & $* * * *$ & - \\
$\mathrm{T}_{\max }\left({ }^{\circ} \mathrm{C}\right)$ & - & - & - \\
Rainfall $(\mathrm{mm})$ & - & $* * * *$ & $* * * *$ \\
\hline
\end{tabular}

Post-hoc comparison analysis (Tukey's HSD test) was carried out in order to quantify significant differences among the test sites. To verify the goodness-of-fit of predictions obtained from the decomposition model, ANOVA and linear regression analysis were carried out to test the relationship between simulated and measured data. All statistical analyses were performed using the software package Statistica ${ }^{\circledR} 8.0$ (Stat Soft Inc., Tulsa, OK, USA).

\section{Results}

Climatic differences between test sites

The MANOVA analysis of climatic variables (precipitation, average, minimum and maximum temperature) carried out over the whole experimental period (January 2011 to June 2012) revealed significant differences among test sites $(\mathrm{F}=106.76, \mathrm{p}<0.01)$. However, the post hoc analysis highlighted that these differences were due to the different homogeneous groups (test sites) with re- spect to some variables, such as mean temperature or rainfall (Tab. 3 )

According to the Kaiser's criterion (1960), PCA results revealed that average and maximum temperature had the largest weight on the PC model, which accounted for $95.8 \%$ of the total variation (eigenvalues: 2.83 and 1.00 , respectively), while precipitation appeared to have not significant effects (eigenvalue $<0.01$ ). As a consequence, a greater weight has been assigned to temperature than to precipitation, and temperature has been used as an important variable to discriminate different climatic decomposition indexes $(C D I s)$.

\section{Evaluation of decay dynamics at the test} sites and litter quality

The litterbag method has been widely utilized to quantify the litter mass decay over time. However, we observed that decomposition rates were overestimated both in early and late phases of the process when the coarse-mesh $(10 \mathrm{~mm})$ litterbags were uti-

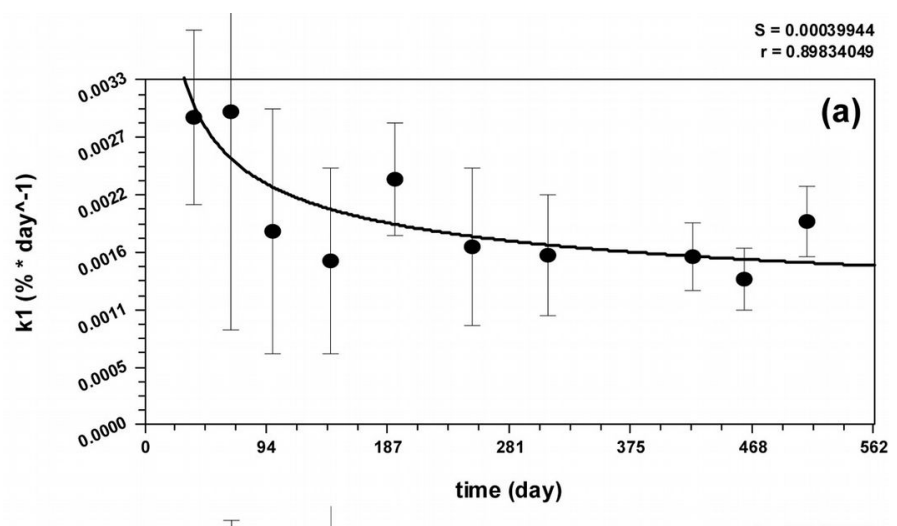

Fig. 3 - Values of $k_{1}(t)$ and $k_{2}(t)$ measured and interpolated by: (a) the Harris' model; (b) the quadratic curve.

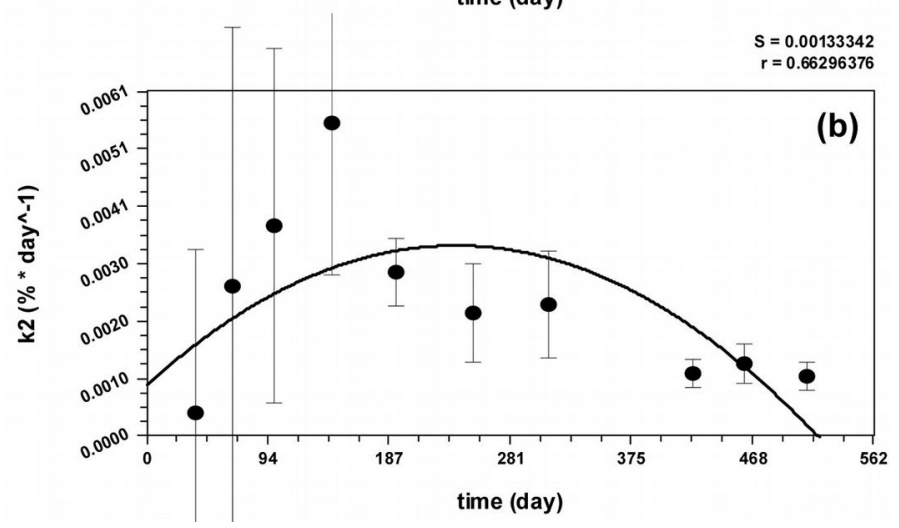



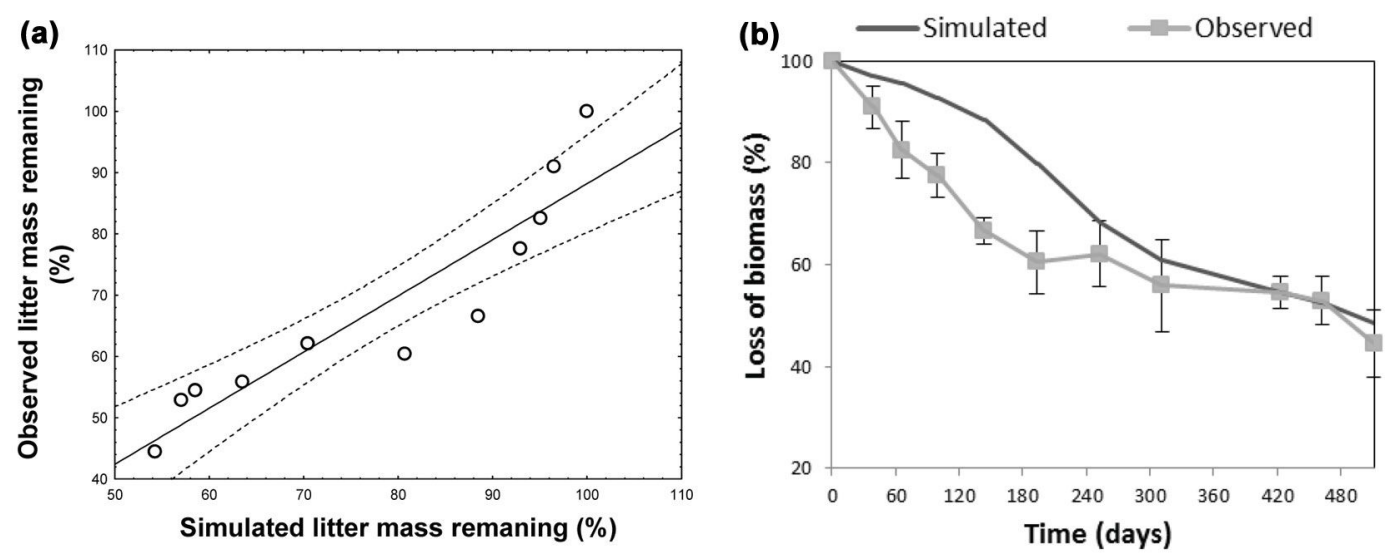

Fig. 4 - Scatter plots (a) and decay curves (b) showing the comparison between observed and simulated data for the site located at Monti Lucretili.

lized. This was likely due to losses of organic matter not related to the decomposers' activity. Although the use of fine-mesh (3 $\mathrm{mm}$ ) bags could reduce the decay rates by excluding some invertebrates, errors in the estimation of decomposition rates resulted higher when coarse-mesh bags were used Therefore, the decomposition model has been parametrized using only data from finemesh litterbags. The litter mass decay over time is displayed in Fig. 3, where a marked reduction of leaf litter mass (10-14\%) was evident just after one month of permanence to the ground, likely due mainly to the leaching of soluble compounds from litter. In this early phase, no significant differences among sites were observed $(F=1.610, p=0.200)$. In winter, the decomposition rate of the site Boschi di Pietralunga (the northern site) was slower than those of the other sites, losing about $10 \%$ less of biomass $(\mathrm{F}=6.948, \mathrm{p}<$ 0.01 ) after 100 days since the beginning of the experiment. Biomass differences between the site Boschi di Pietralunga and the others became more evident after 140 days $(\mathrm{F}=$ 11.499, $\mathrm{p}<0.01$; Tukey's HSD test: Boschi di Pietralunga vs. Monti Picentini, $\mathrm{p}=0.046$; and Boschi di Pietralunga vs. Monti Lucretili, $\mathrm{p}=0.030$ ). Finally, no significant differences $(F=1.99, p=0.137)$ were observed among test-sites at the end of the experiment (after 520 days). Data concerning the leaf lit- ter weight decay at the three sites are presented in Appendix 1. Initial content of lignin, $\mathrm{N}$ and $\mathrm{C}$ concentrations of the leaf litter were $38 \pm 2.6 \%, 2.37 \pm 0.05 \mathrm{mg} \mathrm{g}_{\mathrm{DW}^{-1}}$ and $50.04 \pm 0.14 \mathrm{mg} \mathrm{g}_{\mathrm{DW}^{-1}}{ }^{-1}$, respectively.

\section{Assessment of time-depending equations} for decomposition rates

Equations describing the decomposition rates [ $k_{1}(t)$ and $k_{2}(t)$, eqn. 6 and eqn. 7] have been obtained by fitting the data obtained from the Regional Park of Monti Lucretili (Fig. 3). The Harris' model and the quadratic curve were the best fitting models for $k_{1}(t)(r$ $=0.90)$ and $k_{2}(t)(r=0.66)$ decomposition rates, respectively. The processes modeled
Boschi di Pietralunga

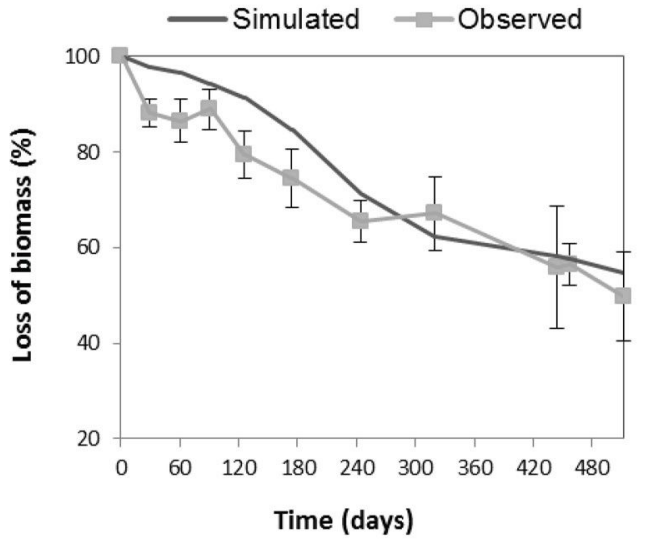

(c)

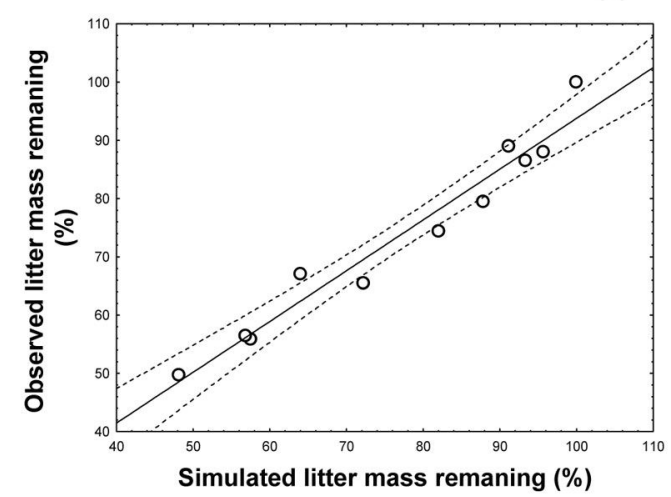

Monti Picentini

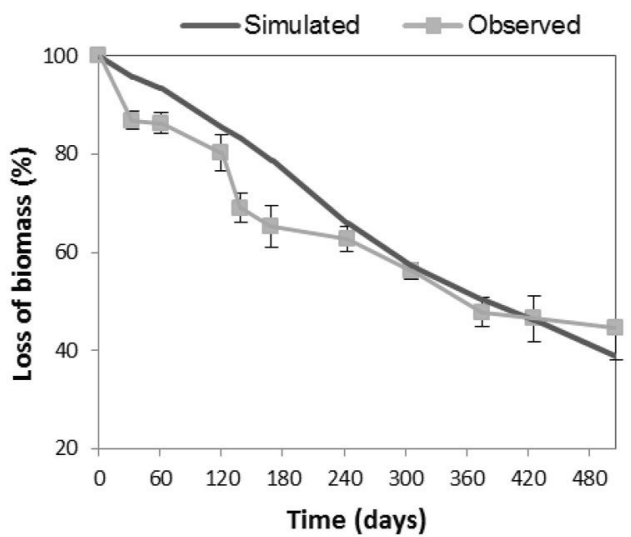

(d)

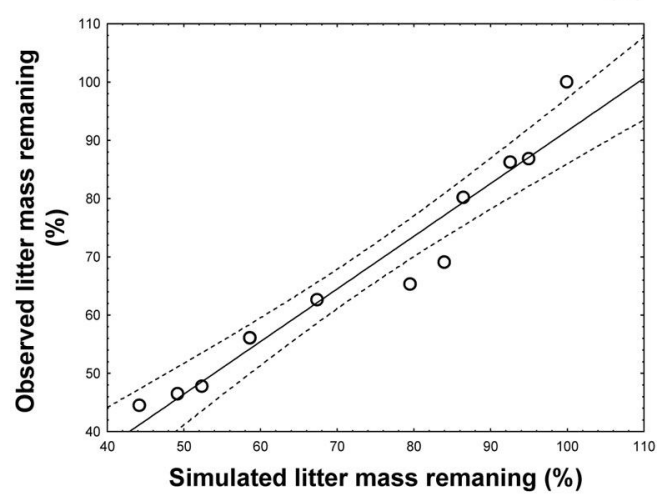

(b) Fig. 5 - (Upper panels): observed and simulated values of mass loss with time at two study sites: (a) Boschi di Pietralunga; (b) Monti Picentini. (Lower panels): comparisons between observed and simulated data obtained at two study sites: (c) Boschi di Pietralunga; (d) Monti Picentini. 
Fig. 6 - (Upper panels): observed and simulated values of mass loss with time at the validation site: (a) Quercus suber; (b) Q. canariensis. (Lower panels): comparisons between observed and simulated values obtained at the validation site: (c) Quercus suber; (d) Q. canariensis.

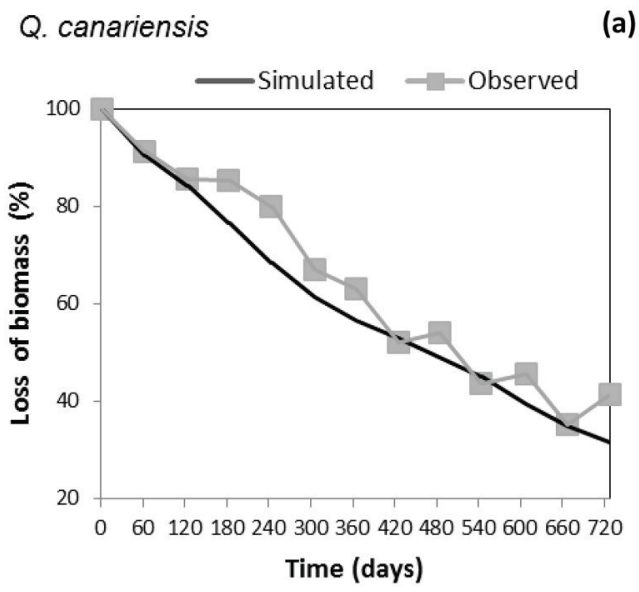

(c)

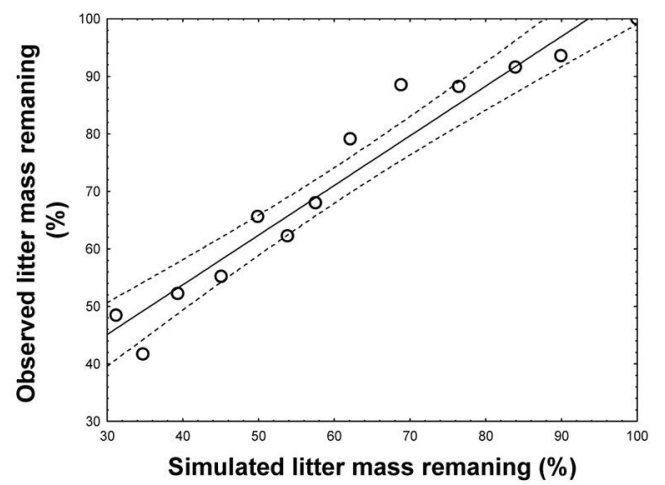

Q. suber

(c)

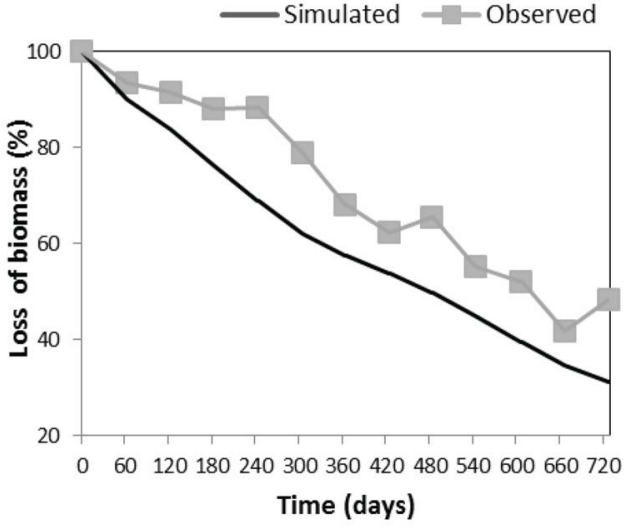

(d)

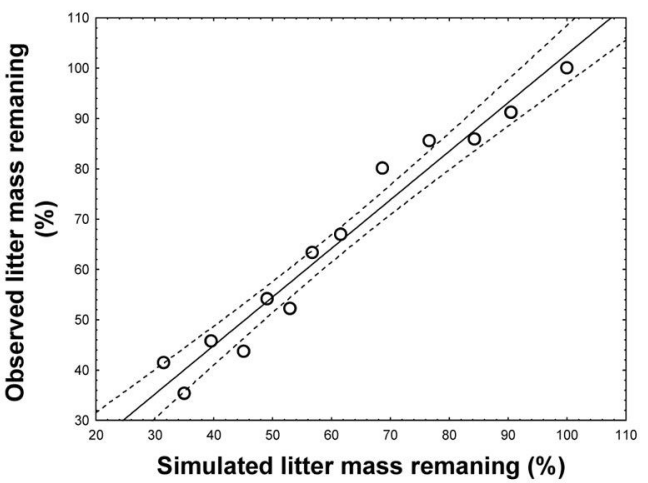

the litter during winter months (i.e., Boschi di Pietralunga), in agreement with Johansson et al. (1995) and Berg \& McClaugherty (2008). On the other hand, sites characterized by cold winter and hot summer (such as the regional Park of Monti Lucretili) exhibited a decay rate strongly affected by temperature extremes. In such locations, decomposition rates were reduced by cold winter and increased by warm summer, providing thus favorable conditions for the decomposers' activity. Finally, sites characterized by mild winter, such as the Regional Park of Monti Picentini, were less affected by temperature, likely due to the rapid acclimation of soil microorganisms to temperature fluctuations along the season (Lou et al. 2001). Furthermore, mild winter temperature may lead to a rapid consumption of easy-decomposable resources before spring and, as a consequence, a deficiency of substrate suitable for decomposers (Eliasson et al. 2005). Indeed, in this study a high variability of the remaining mass in the litter bags was observed at the end of the experimental period. This was likely due to different local climatic conditions, which were caused by site-specific characteristics, thus affecting the decomposition rate of each litter bag.

The model proposed in this study proved to simulated quite accurately the early stage decomposition dynamic for Mediterranean mixed woods. Although the model was based 
on a consolidated approach, the time-based decomposition rates are a novel mathematical implementation. Notably, these equations were not site-specific and were applied indiscriminately to the all study sites.

Different local climates required differen approaches for modeling the litter decomposition process, which is highly dependent on temperature in Mediterranean ecosystems. Moreover, by comparing the experimental litter mass loss to its model predictions (data not shown), we noticed that labile and recalcitrant litter components did respond differently to changes in the climatic conditions. Furthermore, the application of the decomposition model optimized for mixed woods of central Italy to the hot and dry site in Monte la Sauceda (Spain), allowed us to better focus on the most important aspects of the model in order to improve its performances under different environmental conditions. Despite the model overestimation of mass losses in the $Q$. suber litter at the validation site, simulated values did not exceed $10 \%$ of deviation from experimental data. Such discrepancy was likely stemming from unwanted physicochemical processes occurring in the litterbags, such as photodegradation, fragmentation induced by raindrop splash, soil erosion and runoff (Whitford 2002, Dirks et al. 2010, Berhe 2012).

\section{Conclusion}

The decomposition model developed in this study is able to describe the early stages of leaf litter decomposition along a climatic gradient in the Mediterranean mixed woods using few important geo-climatic parameters. Despite some systematic deviations of predictions from observed data were detected, the model may represent an operational compromise between formal simplicity and satisfactory reliability of simulations, as demonstrated by the strong correlations between observed and predicted values. Although different local microclimates required different approaches for modeling the litter decomposition process, the model achieved can take into account the heterogeneity of the Mediterranean environment. Notably, the general time-based equations for modeling the decomposition rates resulted not site-specific, though derived from experimental data.

The litter decomposition model presented here will be next embedded in a processbased model for the quantification of carbon assimilation (photosynthesis) and autotrophic respiration, thereby allowing an assessment of the carbon balance for the considered forest ecosystem under different microclimates. The final aim is to provide forest managers with an important tool for assessing the effect of different managing activities on the carbon balance of forest ecosystems.

\section{Acknowledgements}

The authors wish to thank the Regional Agency for Development and Innovation of Agriculture of Lazio (ARSIAL) and the Campania Regional Council (A.G.C. Ecologia, Tutela Ambiente, C.I.A. Protezione Civile; Settore Programmazione interventi di Protezione Civile sul Territorio; Servizio 04) for providing climatic data. Furthermore, we are grateful to the staff of the Regional Parks of Monti Lucretili, Monti Picentini and Boschi di Pietralunga, and $\mathrm{Dr}$ G. Galante for their logistic support.

\section{References}

Adair EC, Parton J, Del Grosso AJ, Silver WL, Harmon ME, Hall SA, Burke IC, Hart SC (2008). Simple three-pool model accurately describe patterns of long-term litter decomposition in diverse climates. Global Change Biology 14 : 2636-2660. - doi: 10.1111/j.1365-2486.2008.01 674.x

Allen RG, Pereira LS, Raes D, Smith M (1998). Crop evapotranspiration - guidelines for computing crop water requirements. FAO Irrigation and Drainage paper 56, FAO, Food and Agriculture Organization of the United Nations, Rome, Italy, pp. 15.

Berg B, McClaugherty C (2008). Plant Litter: decomposition, humus formation, carbon sequestration $\left(2^{\text {nd }} e d n\right)$. Springer, Berlin, Germany, pp. 340.

Berg B, Berg MP, Bottner P, Box E, Breymeyer A, de Anta RC, Couteaux M, Escudero A, Gallardo A, Kratz W, Madeira M, Mälkönen E, Mcclaugherty C, Meentemeyer V, Muñoz F, Piussi P, Remacle J, de Santo AV (1993). Litter mass loss rates in pine forests of Europe and Eastern United States: some relationships with climate and litter quality. Biogeochemistry 20 (3): 127159. - doi: 10.1007/BF00000785

Berhe AA (2012). Decomposition of organic substrates at eroding vs. depositional landforms positions. Plant and Soil 350 (1): 261-280. - doi: 10.1007/s11104-011-0902-z

Burke IC, Kaye JP, Bird SP, Hall SA, McCulley RS, Sommerville G (2003). Evaluating and testing models of terrestrial biogeochemistry: the role of temperature in controlling decomposition. In: "Models in ecosystems science" (Canham CD, Cole JJ, Lauenroth WK, eds). Princeton University Press, Princeton, New Jersey, USA, pp. 225-253. [online] URL: http://books.google.com/books?id=ffI9ICV10GcC

Carpenter RS (1982). Comparison of equations for decay of leaf litter in tree-hole ecosystems. Oikos 39: 17-22. - doi: 10.2307/3544526

Chertov OG, Komarov AS, Nadporozhskaya M, Bykhovets SS, Zudin SL (2001). ROMUL - a model of soil organic matter dynamics as a substantial tool for forest ecosystem modelling. Ecological Modelling 138: 289-308. - doi: 10.1016/ S0304-3800(00)00409-9

Cooke RC, Whipps JM (1993). Ecophysiology of Fungi. Blackwell, Oxford, UK, pp. 337. [online] URL: http://www.cabdirect.org/abstracts/19932 339778.html

Currie WS, Aber JD (1997). Modelling leaching as a decomposition process in humid Montane forests. Ecology 78: 1844-1860. - doi: 10.1890/ 0012-9658(1997)078[1844:MLAADP]2.0.CO;2 Del Grosso SJ, Parton WJ, Mosier AR, Holland EA, Pendall E, Schimel DS, Ojima DS (2005). Modeling soil $\mathrm{CO}_{2}$ emissions from ecosystems. Biogeochemistry 73: 71-91. - doi: 10.1007/s10 533-004-0898-z

Dirks I, Navon Y, Kanas D, Dumbur R, Grünzweig JM (2010). Atmospheric water vapor as driver of litter decomposition in Mediterranean shrubland and grassland during rainless seasons. Global Change Biology 16(10): 2799-2812. doi: $10.1111 /$ j.1365-2486.2010.02172.x

Eliasson PE, McMurtrie RE, Pepper DA, Strömgren M, Linder S, Årgen GI (2005). The response of heterotrophic $\mathrm{CO}_{2}$ flux to soil warming. Global Change Biology 11: 167-181. - doi: 10.1111/j.1365-2486.2004.00878.x

Epstein HE, Burke IC, Lauenroth WK (2002). Regional patterns of decomposition and primary production rates in the US Great Plains. Ecology 83: 320-327. - doi: 10.1890/0012-9658(2002) 083[0320:RPODAP]2.0.CO;2

Ezcurra E, Becerra J (1987). Experimental decomposition of litter from Tamaulipan cloud forest. A comparison of four simple models. Biotropica 19: 290-296. - doi: 10.2307/2388624

Fioretto A, Di Nardo C, Papa S, Fuggi A (2005). Lignin and cellulose degradation and nitrogen dynamic during decomposition of three leaf litter species in a Mediterranean ecosystem. Soil Biology and Biochemistry 37: 1083-1091. - doi: 10.1016/j.soilbio.2004.11.007

Gallardo A, Merino J (1993). Leaf decomposition in two Mediterranean ecosystems of southwest of Spain: influence of substrate quality. Ecology 74: 152-161. - doi: 10.2307/1939510

Giardina CP, Ryan MG (2000). Evidence that decomposition rates of organic carbon in mineral soil do not vary with temperature. Nature 404: 858-861. - doi: 10.1038/35009076

Giorgi F, Lionello P (2008). Climate change projections for the Mediterranean region. Global and Planetary Change 63: 90-104. - doi: 10.101 6/j.gloplacha.2007.09.005

Giorgi F (2006). Climate change hot-spots. Geophysical Research Letters 33 (8): L08707. - doi: 10.1029/2006GL025734

Gratani L, Foti I (1998). Estimating forest structure and shade tolerance of the species in a mixed deciduous broad-leaved forest in Abruzzo, Italy. Annales Botanici Fennici 35: 75-83. [online] URL: http://www.sekj.org/PDF/anbf35/an bf35-075p.pdf

Gupta SC, Larson WE (1979). Estimating soil water retention characteristics from particle size distribution, organic matter content and bulk density. Water Resources Research 15: 1633 1635. - doi: 10.1029/WR015i006p01633

Hobbie SE (2005). Contrasting effects of substrate and fertilizer nitrogen on the early stages of litter decomposition. Ecosystems 8: 644-656. - doi: 10.1007/s10021-003-0110-7 
Hyams DG (2010). CurveExpert software. Web site. [online] URL: http://www.curveexpert.net Jenny H, Gassel SP, Bingham FT (1949). Comparative study of decomposition rates of organic matter in temperate and tropical region. Soil Science 68: 419-432. - doi: 10.1097/00010694194912000-00001

Johansson MB, Berg B, Meentemeyer V (1995). Litter mass-loss rates in late stage of decomposition in a climatic transect of pine forest. Longterm decomposition in a Scots pine forest. Canadian Journal of Botany 73: 1509-1521. - doi: 10.1139/b95-163

Kaiser HF (1960). The application of electronic computers to factor analysis. Educational and Psychological Measurement 20: 141-151. - doi: 10.1177/001316446002000116

Liski J, Nissinen A, Erhard M, Taskinen O (2003). Climatic effects on litter decomposition from arctic tundra to tropical rainforest. Global Change Biology 9: 1-10. - doi: 10.1046/j.13652486.2003.00605.x

Liski J, Palosuo T, Peltoniemi M, Sievänen R (2005). Carbon and decomposition model Yasso for forest soils. Ecological Modelling 189: 168182. - doi: 10.1016/j.ecolmodel.2005.03.005

Lloyd J, Taylor JA (1994). On the temperature-dependence of soil respiration. Functional Ecology 8: 315-323. - doi: 10.2307/2389824

Lou Y, Wan S, Hui D, Wallace L (2001). Acclimation of soil respiration to warming in tall grass prairie. Nature 613: 622-625. - doi: 10.1038/35 098065

Louisier JD, Parkinson D (1979). Litter decomposition in a cool temperate deciduous forest Canadian Journal of Botany 54: 419-436. - doi 10.1139/b76-041

Meentemeyer V (1978). Macroclimate and lignin control of litter decomposition rates. Ecology 59: 465-472. - doi: 10.2307/1936576

Minderman G (1968). Addition, decomposition and accumulation of organic matter in forests. Journal of Ecology 56: 355-362. - doi: 10.2307/ 2258238

Mitrakos K (1980). A theory for Mediterranean plant Life. Acta Oecologica 1: 245-252.

Olson JS (1963). Energy storage and the balance of producers and decomposers in ecological system. Ecology 44: 322-331. - doi: 10.2307/1932 179

Parton WJ, Cole CV, Schimel DS (1994). A general model for soil organic matter dynamics: sensitivity to litter chemistry, texture and management. Soil Science Society of America Journal 39: 147-167. [online] URL: http://www.nrel.colostate.edu/projects/century/soilCalculator.htm Rastetter EB, Ryan MG, Shaver GR, Melillo JM, Nadelhoffer KJ, Hobbie JE, Aber JD (1991). A general biogeochemical model describing the responses of the $\mathrm{C}$-cycle and $\mathrm{N}$-cycle in terrestrial ecosystems to changes in $\mathrm{CO}_{2}$, climate, and Ndeposition. Tree Physiology 9: 101-126. - doi: 10.1093/treephys/9.1-2.101

Rawls WJ, Brakensiek DL, Saxton KE (1982). Estimation of soil water properties. Transactions of the ASAE 25 (5): 1316-1320. - doi: 10.13031/ 2013.33720

Ritchie JT (1972). Model for predicting evaporation from a row crop with incomplete cover. Water Resources Research 8: 1204-1213. - doi: 10.1029/WR008i005p01204

Rovira P, Rovira R (2010). Fitting litter decomposition datasets to mathematical curves: Towards a generalised exponential approach. Geoderma 155: 329-343. - doi: 10.1016/j.geoderma.2009.1 1.033

Steward BA, Woolhiser DA, Wischmeir WH, Caro JH, Frere MH (1976). Control of water pollution from cropland. An overview (vol. 2). USDA Agriculture Research Service, Beltsville, MD, USA, pp. 188

Turc L (1954). Le bilan d'eau des sols: relation entre les précipitations, l'évaporation et l'écoulement [Soil water balance: relationship between precipitation, evaporation and runoff]. Annales Agronomiques Série A (5): 491-595. [in French] Van Soest PJ, Wine RH (1968). Determination of lignin and cellulose in acid-detergent fibre with permanganate. Association of Official Analytical Chemists Journal 51: 780-785.

Vitale M, Scimone M, Feoli E, Manes F (2003). Modelling leaf gas exchange to predict functional trends in Mediterranean Quercus ilex forest under climatic change in temperature. Ecological Modelling 166: 123-134. - doi: 10.1016/ S0304-3800(03)00129-7

Whitford W (2002). Ecology of desert systems. Academic Press, San Diego, USA, pp. 343. [online] URL: http://books.google.com/books?id=O Z4hZbXS8IcC

Wieder R, Lang G (1982). A critique of the analytical methods used in examining decomposition data obtained from litter bags. Ecology 63: 1636-1642. - doi: 10.2307/1940104

Yang CF, Janssen BH (2000). A mono-compartment model of carbon mineralization with a dynamic rate constant. European Journal of Soil Science 51: 517-529. - doi: 10.1046/j.1365-2389 2000.00319.x

Zhang C, Meng FR, Trofymow JA, Arp PA (2007). Modelling mass and nitrogen remaining in litterbags for Canadian forest and climate conditions. Canadian Journal of Soil Science 87: 413-432. - doi: 10.4141/S06-034

\section{Supplementary Material}

Appendix 1 - Leaf litter weight decay during the experiment at the three test-sites.

Link:Vitale_1202@supp1001.pdf 